\title{
Resistance to Striga hermonthica in Wild Accessions of the Primary Gene Pool of Pennisetum glaucum
}

\author{
J. P. Wilson, D. E. Hess, and W. W. Hanna
}

First and third authors: U.S. Department of Agriculture-Agricultural Research Service Crop Genetics and Breeding Research Unit, University of Georgia Coastal Plain Experiment Station, Tifton, 31793-0748; and second author: ICRISAT, B.P. 320, Bamako, Mali.

Cooperative research project among the U.S. Department of Agriculture, Agricultural Research Service, the University of Georgia College of Agricultural Experiment Stations, and the International Crops Research Institute for the Semi-Arid Tropics.

Accepted for publication 30 June 2000.

\begin{abstract}
Wilson, J. P., Hess, D. E., and Hanna, W. W. 2000. Resistance to Striga hermonthica in wild accessions of the primary gene pool of Pennisetum glaucum. Phytopathology 90:1169-1172.

Resistance to Striga hermonthica in 274 wild Pennisetum glaucum subsp. monodii and stenostachyum accessions was evaluated at Samanko, Mali in 1997 and 1998, and at Cinzana, Mali and Sadoré, Niger in 1998. Data recorded included number of striga plants per plot at least three times during the season, date of striga emergence, number of Pennisetum plants, Pennisetum anthesis date, and downy mildew incidence (caused by Sclerospora graminicola). Across trials, the average maximum number of striga per host plant ranged from 0.9 to 8.3. Average days to striga emergence ranged from 54 to 68 days across trials, and was negatively correlated $(P<0.01)$ with maximum striga within trials. Days to Pennisetum

flowering ranged from 54 to 74 days across trials. Host flowering was correlated $(P \leq 0.05)$ positively with maximum striga at Samanko in 1997 and 1998, but negatively at Cinzana. Downy mildew incidence ranged from 10 to $32 \%$ across trials, and was negatively correlated with maximum striga in three trials. Days to striga emergence and Pennisetum flowering were significant covariates affecting maximum striga values, but downy mildew incidence was not. Least squares means of maximum striga across trials averaged 5.7, and ranged from -0.2 to 19.1 striga per host plant. Broad-sense heritability of observed maximum striga was estimated to be 0.55. Agar-gel assays conducted in the laboratory were ineffective in identifying differences in stimulating striga seed germination among selected accessions. Variables not directly related to genetic resistance can affect maximum striga emergence in the field, and their identification may allow more effective resistance screening.
\end{abstract}

Cereals and grain legumes are the principal food crops grown in West Africa and provide the main source of human nutrition there. Various species of the parasitic weed striga present serious constraints to cereal and legume production in the sub-Saharan Africa. The major cereal crops; sorghum (Sorghum bicolor), maize (Zea mays), pearl millet (Pennisetum glaucum), and rice (Oryza sativa), as well as sugarcane (Saccharum officinarum) are attacked by S. hermonthica (Del.) Benth. In the West African countries of Benin, Cameroon, Gambia, Ghana, Nigeria, and Togo, 40 to $77 \%$ of grain fields were estimated to be infested by striga (17). Yield losses average 10 to $31 \%$, but in areas of heavy infestation, losses may reach 90 to $100 \%$ in some years. Loss in total grain yield averages 3 to $26 \%$. Twenty-one million hectares of land in Africa are estimated to be infested by striga, resulting in an annual grain yield loss of 4.1 million tons (17) and an estimated overall loss of 7 billion U.S. dollars in revenues to Africa (11).

Integrated striga control strategies used in other crops can be adapted to pearl millet (Pennisetum glaucum [L.] R. Br.) production. Control recommendations for subsistence farmers include reducing the number of striga seeds in the soil and enhancing soil fertility (9). Infection by Striga hermonthica (Del.) Benth. on corn and sorghum can be managed by sound cultural practices and, where available, resistant cultivars $(1,8,15)$. Host plant resistance is the most economic control measure because resistant cultivars can be grown without additional input by the subsistence farmer (7).

Corresponding author: J. P. Wilson; E-mail address: jwilson@tifton.cpes.peachnet.edu

Publication no. P-2000-0822-01R

This article is in the public domain and not copyrightable. It may be freely reprinted with customary crediting of the source. The American Phytopathological Society, 2000.
Little information is available concerning genetic resistance in pearl millet, and there is some controversy whether resistance exists in P. glaucum (3). The wild grassy subspecies monodii and stenostachyum (the primary gene pool of pearl millet) have resistance to a number of major diseases $(6,19)$. However, there are no research reports evaluating this germ plasm for striga resistance. The primary gene pool subspecies were considered to be a useful collection to determine if differences in resistance exist in P. glaucum because there has been no artificial selection for resistance, tolerance, or agronomic performance within the germ plasm. The objective of this experiment was to evaluate a collection of wild $P$. glaucum subsp. monodii and stenostachyum for resistance to $S$. hermonthica.

\section{MATERIALS AND METHODS}

Field trials. Samanko, Mali, 1997. Research plots were planted at the ICRISAT-Mali station (near Bamako) on 11 July 1997. Four replications of 274 accessions of $P$. glaucum subspecies mondii and stenostachyum were planted in two-row plots spaced $50 \mathrm{~cm}$ apart, in a randomized complete-block design. Within each row, four hills spaced $60 \mathrm{~cm}$ apart were planted, and each plot was infested with $3 \mathrm{~g}$ of seeds (approximately 230,000 viable seeds) of S. hermonthica. Stands were thinned to one Pennisetum plant per hill. Data collected included date of striga emergence, number of striga per plot at 28,74 , and 88 days after sowing, number of Pennisetum plants, and date of Pennisetum flowering (days to $50 \%$ anthesis). Downy mildew (infection by Sclerospora graminicola [Sacc.] Schroet.) was minimized by spraying metalaxyl ( $0.5 \mathrm{~g}$ per liter) with a handheld sprayer to runoff on 23 and 69 days after planting. Downy mildew incidence was recorded 102 days after planting. 
Samanko, Mali, 1998. Research plots were planted and infested with striga as described above, except row spacing was $100 \mathrm{~cm}$. Data collected included date of striga emergence, number of striga per plot at 63, 77, and 91 days after planting, number of Pennisetum plants per plot, and date of Pennisetum flowering. Downy mildew was minimized by spraying metalaxyl $(0.5 \mathrm{~g} /$ liter $) 65$ days after planting. Downy mildew incidence was recorded 84 days after planting.

Cinzana, Mali, 1998. Plots were planted at the Institute d'Economie Rurale station (near Segou) in a field naturally infested with striga. Four replications of 267 accessions were planted on 15 July 1998, similar to the 1998 Samanko trial, except the field was not artificially infested with striga seed, and metalaxyl was not sprayed to manage downy mildew epidemic development. Data collected included date of striga emergence, number of striga per plot at 61,75 , and 89 days after sowing, number of Pennisetum plants, and date of Pennisetum flowering. Downy mildew incidence was recorded 82 days after planting.

Sadoré, Niger, 1998. Plots were planted at the ICRISAT-Niger station (near Niamey) in a field naturally infested with striga. Accessions were planted on 1 July 1998, similar to the planting in Cinzana. Only two replications were established because of limited quantities of available seed. Because of poor seedling emergence from drought and survival due to subsequent grasshopper feeding and sandblasting damage, additional seeds were planted in the greenhouse on 9 July 1998 and seedlings were transplanted to the field on 20 July. Data collected include date of striga emergence, number of striga per plot at 51, 63, and 79 days after sowing, number of Pennisetum plants per plot and Pennisetum flowering dates. Downy mildew incidence was recorded 71 days after sowing.

Data analysis of field experiments. Not all Pennisetum accessions were represented by eight hills in each plot, so the mean number of striga per hill within each plot was calculated. Maximum striga number per plant for each plot was determined as the count on the evaluation date that had the greatest number of striga. Number of striga plants within plots frequently declined on the last evaluation date, which is typical of striga infection and independent of Pennisetum genotype. Decline appears to be associated with Fusarium parasitism and drought.

For each variable recorded, data transformations $(\log [\mathrm{N}+0.05]$ or square root $[\mathrm{N}+0.05]$ ) were examined in an attempt to reduce associations between means and variances. Variables within trials were analyzed by the general linear model of SAS (Cary, NC), with sums of squares partitioned into replication and accession. Pearson's correlation coefficients among untransformed accession means were calculated within trials.
Because significant correlations existed among many of the variables examined, the maximum striga number was analyzed by analysis of covariance, with sums of squares partitioned into trial, replication within trial, and accession, with days to striga emergence, days to Pennisetum flowering, and downy mildew incidence as covariates. Least-square means of maximum striga number were estimated for the accessions.

Broad sense heritability of observed maximum striga was estimated. The variance component procedure of SAS was used to determine accession (genotypic) and trial $\times$ accession (phenotypic) variances from the expected mean squares. Heritability was calculated as the ratio of genotypic to phenotypic variances.

Agar-gel assays. Agar-gel assays were conducted to determine if that method could be a useful technique to screen for striga resistance. The relative ability of the wild $P$. glaucum accessions to induce germination of $S$. hermonthica seed were evaluated as described by Hess et al. (8). Based upon data collected in 1997, 13 accessions were selected for variation in maximum striga, days to host flowering, and downy mildew incidence. Controls included the pearl millet landrace "Toronio" and the susceptible sorghum "E 36-1". Each treatment was assessed in petri plates with six replications. In 1998, accessions were evaluated with striga seed collected from parasitized sorghum at Samanko, Mali. In 1999, tests were conducted with striga seed collected from parasitized sorghum at Samanko, Mali, from pearl millet at Bengou, Niger, and from pearl millet at Sadoré, Niger.

After 5 days of incubation, the undersurface of the petri plates was examined under a dissecting microscope to identify germinated striga seeds. Locations of germinated striga seeds were marked and the distance in $\mathrm{mm}$ between the root and the furthest observed germinated seed was measured to determine GD5 (greatest distance after 5 days) values. In 1998, a template with a 6-mm diameter hole was placed on the undersurface of the petri plates. The edge of the template was aligned with the root edge and numbers of germinated and total striga seed were counted in up to four fields on alternating sides of the root, approximately equidistant along its length. Data were analyzed by the general linear model procedure of SAS. Means were differentiated by Fisher's least significant difference (LSD).

\section{RESULTS}

Field trials. The maximum number of observed striga per host plant was greater in the artificially infested trials at Samanko in 1997 and 1998 than in the other trials (Table 1). The average

TABLE 1. Characteristics of wild Pennisetum accessions of the primary gene pool, evaluated for resistance to Striga hermonthica in West Africa ${ }^{\mathrm{w}}$

\begin{tabular}{|c|c|c|c|c|c|}
\hline \multirow[b]{2}{*}{ Trait } & \multirow[b]{2}{*}{ Parameter } & \multicolumn{3}{|c|}{ Mali } & \multirow{2}{*}{$\frac{\text { Niger }}{\text { Sadoré } 1998}$} \\
\hline & & Samanko 1997 & Samanko 1998 & Cinzana 1998 & \\
\hline Maximum striga per plant & $\begin{array}{l}\text { Mean } \\
\text { Range } \\
\text { Accession mean square }\end{array}$ & $\begin{array}{c}8.3 \\
0-46 \\
* *\end{array}$ & $\begin{array}{l}7.2 \\
1-24 \\
* * \mathrm{x}\end{array}$ & $\begin{array}{l}1.7 \\
0-7 \\
* * y\end{array}$ & $\begin{array}{l}0.9 \\
0-8 \\
* \mathrm{x}\end{array}$ \\
\hline Days to striga emergence & $\begin{array}{l}\text { Mean } \\
\text { Range } \\
\text { Accession mean square } \\
\text { Correlation with maximum striga }\end{array}$ & $\begin{array}{c}58 \\
43-80 \\
* * \\
-0.12 *\end{array}$ & $\begin{array}{c}54 \\
35-69 \\
* * z \\
-0.22 * *\end{array}$ & $\begin{array}{c}68 \\
54-80 \\
* * \mathrm{z} \\
-0.36^{* *}\end{array}$ & $\begin{array}{c}58 \\
28-85 \\
\mathrm{~ns}^{\mathrm{z}} \\
-0.29 * *\end{array}$ \\
\hline Days to Pennisetum flowering & $\begin{array}{l}\text { Mean } \\
\text { Range } \\
\text { Accession mean square } \\
\text { Correlation with maximum striga }\end{array}$ & $\begin{array}{l}54 \\
39-79 \\
* * \\
0.54 * *\end{array}$ & $\begin{array}{c}59 \\
48-84 \\
* * \\
0.17 * *\end{array}$ & $\begin{array}{c}56 \\
41-76 \\
* * \\
-0.13 *\end{array}$ & $\begin{array}{c}74 \\
57-79 \\
\text { ns } \\
-0.12+\end{array}$ \\
\hline Downy mildew incidence $(\%)$ & $\begin{array}{l}\text { Mean } \\
\text { Range } \\
\text { Accession mean square } \\
\text { Correlation with maximum striga }\end{array}$ & $\begin{array}{c}32 \\
0-100 \\
* * \\
-0.52 * *\end{array}$ & $\begin{array}{c}26 \\
0-100 \\
* * \\
-0.13 *\end{array}$ & $\begin{array}{c}31 \\
0-100 \\
* * \\
-0.06\end{array}$ & $\begin{array}{c}10 \\
0-100 \\
* * \\
-0.19 * *\end{array}$ \\
\hline
\end{tabular}

${ }^{\mathrm{w}}+, *$, and $* *$ indicate significance at $P=0.10,0.05$, and 0.01 , respectively.

$x$ Analysis of variance conducted on square root (maximum striga +0.05 ).

y Analysis of variance conducted on $\log$ (maximum striga +0.05 ).

${ }^{\mathrm{z}}$ Analysis of variance conducted on $\log$ (days to striga appearance +0.05 ). 
maximum striga was 7.8 in the infested trials, compared to 1.3 in the noninfested trials. Effects due to accessions were significant in all trials.

The days to striga emergence value was greatest at Cinzana, 1998. However, the range of emergence was broadest at Sadoré, 1998 (Table 1). Effects due to accessions were significant in all trials except Sadoré, 1998. Days to striga emergence were negatively correlated with maximum striga in all trials. Across trials, the days to striga emergence value was a significant covariate affecting maximum striga emergence (Table 2).

The days to Pennisetum flowering value was greatest at Sadoré, 1998 compared to the other trials (Table 1). Effects due to accessions were significant in all trials except Sadoré, 1998. The Pennisetum flowering date was correlated positively with maximum striga at Samanko in 1997 and 1998, but negatively at Cinzana, 1998. Across trials, the days to Pennisetum flowering value was a significant covariate affecting maximum striga emergence (Table 2).

Of all of the trials, downy mildew incidence was lowest at Sadoré, 1998 (Table 1). Effects due to accessions were significant in all trials. Downy mildew incidence was negatively correlated with maximum striga in all trials except Cinzana, 1998. Across trials, downy mildew incidence was not a significant covariate affecting maximum striga values (Table 2). Analysis of covariance of maximum striga values was conducted across trials to correct for the covariates days to striga emergence and days to Pennisetum flowering. Least squares means of maximum striga per plant for accessions over all trials averaged 5.7, and ranged from -0.2 for PS 629 to 19.1 for PS 427. Based upon $t$ tests, least squares means of maximum striga for 157 accessions did not differ $(P=0.05)$ from zero.

Variance component analysis of observed striga allowed derivation of genotypic and phenotypic variances from the expected mean squares. The ratio of genotypic to phenotypic variances, or broad-sense heritability for maximum striga per plant within the sample of the wild Pennisetum spp. was determined to be 0.55 .

Agar-gel assays. Accession was a significant $(P<0.01)$ source of variation for percent germination of striga seed and GD5 in 1998. In 1999, striga seed origin and accessions were significant $(P<0.01)$ for variation in GD5, however, striga origin $\times$ accession interaction was not significant, indicating no discernible host specificity. The wild Pennisetum induced less average striga seed germination $(0.4 \%)$ compared to the pearl millet landrace Toronio (4.0\%) and sorghum E 36-1 (13.8\%) in 1998 (Table 3). The GD5 reactions were similar in both tests. GD5 values were greater for E 36-1 (average $=22.7$ ) and Toronio (average $=7.6$ ) than for the wild accessions. Some variation existed among the wild Pennisetum in the 1999 test, but all induced less striga germination than the cultivated pearl millet landrace and sorghum. GD5 values for striga seed from Samanko (4.08), Sadoré (2.86), and Bengou (2.86) differed $(\mathrm{LSD}=0.70)$. Although differences were apparent in least squares means of maximum striga per plant across the four field trials, these differences were not expressed in their ability to induce striga seed germination.

TABLE 2. Analysis of covariance of characteristics of wild Pennisetum accessions of the primary gene pool evaluated for resistance to Striga hermonthica in West Africa

\begin{tabular}{lrc}
\hline Source of variation & \multicolumn{1}{c}{$\mathrm{df}^{\mathrm{y}}$} & Mean square \\
\hline Trial & 3 & $3,521.3^{* * \mathrm{z}}$ \\
Replication (trial) & 10 & $723.7^{* *}$ \\
Accession & 273 & $81.3^{* *}$ \\
Days to striga emergence & 1 & $4,942.5^{* *}$ \\
Days to Pennisetum flowering & 1 & $2,981.3^{* *}$ \\
Downy mildew incidence & 1 & 68.9 \\
Error & 2,680 & 47.9 \\
\hline
\end{tabular}

y Degrees of freedom.

${ }^{\mathrm{z}}$ Significant at $P<0.01$.

\section{DISCUSSION}

Heritable differences in striga colonization were identified among these wild Pennisetum accessions. Expression of resistance in the field is apparently confounded by several factors which affect accurate identification of resistance. A laboratory assay which has been effective for identifying resistance in sorghum was not effective in differentiating among the wild Pennisetum accessions.

Effectively identifying resistance requires identifying and controlling factors affecting maximum striga. One factor presumed to exist, but not evaluated in these experiments, is genetic heterogeneity for resistance within the wild accessions. A subset of these accessions was heterogeneous for resistance to rust and Pyricularia leaf spot (19). In the present trials, many accessions were heterogeneous for downy mildew resistance. It is highly probable that heterogeneity for striga resistance likewise exists.

The days to striga emergence value was a significant covariate affecting maximum striga emergence. Several variables might account for differences in days to striga emergence, including differences in host root system proliferation or architecture, early carbohydrate partitioning from host to pathogen, or in quantities or types of exudates which induce germination of striga seed. Parker and Wilson (12) evaluated resistance in semiwild 'shibras', which are naturally occurring hybrids derived from spontaneous crosses between wild and cultivated $P$. glaucum. Progeny of the shibra plants tended to induce less germination of striga seed than did the landrace variety "Ex Bornu". There was generally a greater response in striga germination assays than expected based upon the high level of resistance observed within their pot tests, which is contrary to our results. We observed relatively high levels of striga emergence in the field on some accessions, but all wild accessions induced low levels of striga seed germination. Differences between the germination assay protocol, conditions in pot vs. field trials, and the specific germ plasm evaluated make it difficult to draw conclusions about the discrepancies between our experiments and those of Parker and Wilson (12). In fact, Ramaiah (13) later considered Parker and Wilson's (12) germ plasm selections to be susceptible.

The agar-gel assays were ineffective for identifying resistance; therefore, differences in stimulant production are not likely to be

TABLE 3. Striga hermonthica seed germination in response to wild Pennisetum accessions of the primary gene pool in agar-gel assays

\begin{tabular}{|c|c|c|c|c|}
\hline Accession & $\begin{array}{l}\text { Maximum } \\
\text { striga Ls } \\
\text { mean }^{v}\end{array}$ & $\begin{array}{c}\text { Striga seed } \\
\text { germination }(\%) \\
1998\end{array}$ & $\begin{array}{l}\text { GD5 }^{w} \\
1998\end{array}$ & $\begin{array}{l}\text { GD5 } \\
1999\end{array}$ \\
\hline PS 64 & $10.1 * * \mathrm{x}$ & $0.30 \mathrm{a}^{\mathrm{y}}$ & $1.5 \mathrm{a}$ & $0.5 \mathrm{a}-\mathrm{c}$ \\
\hline PS 132 & $9.9 * *$ & $0.00 \mathrm{a}$ & $0.0 \mathrm{a}$ & $0.0 \mathrm{a}$ \\
\hline PS 190 & $6.4^{*}$ & $0.00 \mathrm{a}$ & $0.8 \mathrm{a}$ & $0.5 \mathrm{a}-\mathrm{c}$ \\
\hline PS 208 & $8.2 * *$ & $0.83 \mathrm{a}$ & $2.5 \mathrm{a}$ & $0.9 \mathrm{a}-\mathrm{c}$ \\
\hline PS 212 & $8.1 * *$ & $0.11 \mathrm{a}$ & $3.5 \mathrm{a}$ & $2.7 \mathrm{~d}$ \\
\hline PS 287 & 2.7 & $0.89 \mathrm{a}$ & $3.0 \mathrm{a}$ & $1.5 \mathrm{a}-\mathrm{d}$ \\
\hline PS 427 & $19.1 * *$ & $0.30 \mathrm{a}$ & $1.8 \mathrm{a}$ & $0.9 \mathrm{a}-\mathrm{c}$ \\
\hline PS 428 & $14.3 * *$ & $0.00 \mathrm{a}$ & $0.0 \mathrm{a}$ & $0.5 \mathrm{a}-\mathrm{c}$ \\
\hline PS 459 & 2.3 & $1.32 \mathrm{a}$ & $1.7 \mathrm{a}$ & $1.8 \mathrm{~cd}$ \\
\hline PS 549 & 1.6 & $0.73 \mathrm{a}$ & $3.7 \mathrm{a}$ & $1.6 \mathrm{~b}-\mathrm{d}$ \\
\hline PS 555 & 1.9 & $0.86 \mathrm{a}$ & $2.6 \mathrm{a}$ & $1.4 \mathrm{a}-\mathrm{d}$ \\
\hline PS 622 & $7.5^{* *}$ & $0.49 \mathrm{a}$ & $1.8 \mathrm{a}$ & $1.6 \mathrm{a}-\mathrm{d}$ \\
\hline PS 755 & $11.9 * *$ & $0.00 \mathrm{a}$ & $0.0 \mathrm{a}$ & $0.1 \mathrm{ab}$ \\
\hline Toronio & & $4.03 \mathrm{~b}$ & $8.8 \mathrm{~b}$ & $6.4 \mathrm{e}$ \\
\hline E 36-1 (sorghum) & & $13.75 \mathrm{c}$ & $23.5 \mathrm{c}$ & $21.9 \mathrm{f}$ \\
\hline $\operatorname{LSD}^{\mathrm{z}}(0.05)$ & & 2.29 & 4.2 & 1.6 \\
\hline \multicolumn{5}{|c|}{$\begin{array}{l}{ }^{\mathrm{v}} \text { Least-squares means determined from analysis of covariance of data from } \\
\text { four locations. }\end{array}$} \\
\hline \multicolumn{5}{|c|}{$\begin{array}{l}{ }^{\mathrm{w}} \text { Greatest distance (in } \mathrm{mm} \text { ) of germinated striga seeds from the root after five } \\
\text { days of incubation. }\end{array}$} \\
\hline \multicolumn{5}{|c|}{$\mathrm{x} *$ and $* * ;$ value differs from zero at $P=0.05$ and 0.01 , respectively. } \\
\hline \multicolumn{5}{|c|}{$\begin{array}{l}\text { y Values within a column followed by a common letter do not differ by Fisher's } \\
\text { LSD. }\end{array}$} \\
\hline
\end{tabular}

Vol. 90 , No. 10,2000 
responsible for differences in striga infestation observed in the field. Although differences in germination stimulant were evident between the wild and cultivated pearl millet and sorghum, differences among the wild accessions were insignificant. An alternative mechanism, other than low exudation of germination stimulants, appears to be responsible for differences in striga infestation among these accessions.

Host plant maturity is another significant covariate confounding accurate identification of resistance. The confounding effect of host maturity on disease expression and epidemic development is common for foliar diseases of pearl millet, and accurate assessment of resistance often requires analytic adjustment for host maturity $(18,20)$. Although the Pennisetum-striga pathosystem differs significantly from a fungal disease of the foliage, a relationship between $S$. hermonthica infection of maize and date of maturity has been previously observed (16). In that study, earlierflowering maize genotypes supported less striga.

The effect of maturity is not consistent among experiments. Ramaiah (14) reported selection of pearl millets with lower levels of striga. Many of the resistant selections flowered earlier than the susceptible control and the local variety. However, in another experiment, the later maturing selections tended to be more resistant than the early selections (14). Relationships with maturity were inconsistent in our trials, as indicated by the occurrence of both positive and negative correlations with maximum striga.

Downy mildew incidence was not a significant covariate affecting maximum striga; however, significant negative correlations existed in three of the field trials. Little is known about interactions between Striga hermonthica and Sclerospora graminicola. Presumably, host photosynthesis would be disrupted by both pathogens, and competitive carbohydrate partitioning would occur among the host and the two obligate parasites. $S$. hermonthica infection can reduce growth of pearl millet plants by $28 \%$ (5). Of that reduction, $16 \%$ is the result of carbohydrate allocation from the host to parasite, and $84 \%$ is the result of reduced photosynthesis of the host. Chlorophyll content is reduced in downy mildew infected pearl millet (2) with the likely result of reduced photosynthetic efficiency. Effects of interaction between these obligate parasites requires further clarification.

Selection for low striga number has not resulted in significant improvements in crop resistance (10). Likewise, selecting and breeding sorghums for resistance based strictly on field evaluations has not been very successful (4). Low striga number is an important selection criterion. However, if expression of that trait is affected by factors unrelated to genetic resistance, then slow or no progress from selection is inevitable. Our experiments demonstrate striga numbers on Pennisetum were affected by the days to striga emergence and host maturity. Analyses which correct for these and other identifiable variables are likely to improve resistance screening protocols.

\section{ACKNOWLEDGMENTS}

This research was funded in part by a USAID-sponsored Initiative on Development of Linkages with International Agricultural Research Centers and the U.S. Department of Energy Grant DE-FG02-93ER20099.

\section{LITERATURE CITED}

1. Berner, D. K., Kling, J. G., and Singh, B. B. 1995. Striga research and control. A perspective from Africa. Plant Dis. 79:652-660.

2. Bhatia, J. N., and Thakur, D. P. 1991. Chlorophyll content and mineral composition of pearl millet leaves infected with downy mildew disease. Indian J. Plant Physiol. 34:198-201.

3. Chisi, M., and Esle, P. 1997. Discussion for Session VII-Breeding for resistance to other abiotic stresses and Striga. Pages 525-528 in: Proc. Int. Conf. Genetic Improvement of Sorghum and Pearl Millet. INTSORMIL, Lincoln, NE.

4. Ejeta, G., Butler, L. G., Hess, D. E., Obilana, T., and Reddy, B. V. 1997. Breeding for Striga resistance in sorghum. Pages 504-516 in: Proc. Int. Conf. Genetic Improvement of Sorghum and Pearl Millet. INTSORMIL, Lincoln, NE.

5. Graves, J. D., Wylde, A., Press, M. C., and Stewart, G. R. 1990. Growth and carbon allocation in Pennisetum typhoides infected with the parasitic angiosperm Striga hermonthica. Plant, Cell, Environ. 13:367-373.

6. Hanna, W. W., Wilson, J. P. Wells, H. D., and Gupta, J. C. 1993. Registration of Tift \#5 S-1 germ plasm. Crop Sci. 33:1417-1418.

7. Hess, D. E., and Ejeta, G. 1992. Inheritance of resistance to Striga in sorghum genotype SRN39. Plant Breed. 109:233-241.

8. Hess, D. E., Ejeta, G., and Butler, L. G. 1992. Selecting sorghum genotypes expressing a quantitative biosynthetic trait that confers resistance to Striga. Phytochemistry 31:493-497.

9. Hess, D. E., Obilana, A. B., and. Grard, P. 1996. Striga research at ICRISAT. Pages 828-834 in: Advances in Parasitic Plants. J. I. Cubero, D. Berner, D. Joel, L. J. Musselman, and C. Parker, eds. Research. Sevilla: Dirección General de Investagición Agraria.

10. Kim, S. K., Fajemisin, J. M., The, C., Adepoju, A., Kling, J., Badu-Apraku, B., Versteeg, M., Carsky, R., and Lagoke, S. T. O. 1998. Development of synthetic maize populations for resistance to Striga hermonthica. Plant Breed. 117:203-209.

11. M'Boob, S. S. 1989. A regional programme for West and Central Africa. Pages 190-194 in: Proc. FAO/OAU All-African Government Consultation on Striga Control. FAO Plant Protection Paper 96.

12. Parker, C., and Wilson, A. K. 1983. Striga-resistance identified in semiwild 'shibra' millet (Pennisetum sp.). Med. Fac. Landbouww. Rijksuniv. Genet. 48:1111-1117.

13. Ramaiah, K. V. 1984. Patterns of Striga resistance in sorghum and millets with special emphasis on Africa. Striga: Biology and Control. Pages 71-92 in: Proceedings of the Workshop on the Biology and Control of Striga, 1983, Dakar, Senegal. ICSU Press, Paris.

14. Ramaiah, K. V. 1991. Breeding for Striga resistance in sorghum and millet. Pages 75-80 in: Combating Striga in Africa: Proc. Int. Workshop. IITA, Ibadan, Nigeria.

15. Ramaiah, K. V., and Parker, C. 1982. Striga and other weeds in Sorghum. Pages 291-302 in: Sorghum in the Eighties. Proc. Int. Symp. Sorghum. International Crops Research Institute for the Semi-Arid Tropics, Andhra Pradesh, India.

16. Ransom, J. K., and Odhiambo, G. D. 1995. Effect of corn (Zea mays) genotypes which vary in maturity length on Striga hermonthica parasitism. Weed Technol. 9:63-67.

17. Sauerborn, J. 1991. The economic importance of the phytoparasites Orobanche and Striga. Pages 137-143 in: Proc. Int. Symp. Parasitic Weeds, 5th. J. K. Ransom, L. J. Musselman, D. Worsham, and C. Parker, eds. International Maize and Wheat Improvement Center, Mexico, D.F.

18. Wilson, J. P., and Gates, R. N. 1999. Disease resistance and biomass stability of forage pearl millet hybrids with partial rust resistance. Plant Dis. 83:733-738.

19. Wilson, J. P., and Hanna, W. W. 1992. Disease resistance in wild Pennisetum species. Plant Dis. 76:1171-1175.

20. Wilson, J. P., and Hanna, W. W. 1992. Effects of gene and cytoplasm substitutions in pearl millet on leaf blight epidemics and infection by Pyricularia grisea. Phytopathology 82:839-842. 